\section{IJSR \\ 2,1}

97

\title{
GUINEA FOWL \\ (NUMIDA MELEAGRIS) \\ AS A MEAT BIRD
}

\author{
Aisha Elfaki Mohamed' \\ Wildlife Research Center, Sudan

\section{Zohair Magzoub Mohamed Elhag ${ }^{2}$} \\ Dorcsh Gruppe, UAE
}

\section{Ali Saad Mohamed ${ }^{3}$}

Sudan University of Science and Technology, Sudan

\begin{abstract}
Purpose: The purpose of this study was to determine the meat chemical composition, meat quality attributes and the sensory attributes of the guinea fowl cuts.

Design/methodology/approach: Five diets designated as A (20.5 per cent CP, 2990 kcal ME), B (high protein 26 per cent high energy ( $3150 \mathrm{kcal}), \mathrm{C}$ (high protein 26 per cent: low energy $2800 \mathrm{kcal}$ ), D (low protein 16 per cent: high energy $3150 \mathrm{kcal}$ ) and $\mathrm{E}$ (low protein 15 per cent: low energy $2750 \mathrm{kcal}$ ) were used for feeding five groups of guinea fowl keets. Group (A) served as the control ration.
\end{abstract}

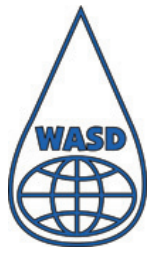

International Journal of Sudan Research Vol. 2 No. 1, 2012
${ }^{1}$ Zohair Magzoub Mohamed Elhag, Dorcsh Gruppe, Abu Dhabi, P. O. Box 26417, UAE ${ }^{2}$ Dr. Aisha Elfaki Mohamed, Wildlife Research Center, Animal Resources Research Corporation, Federal Ministry of Animal Resources, Fisheries and Rangeland, P. O. Box 16, Elmorad Omdurman, Khartoum, SUDAN, Email: aishelfaki@hotmail.com ${ }^{3}$ Prof. Ali Saad Mohamed, Department of Wildlife, College of Animal Production, Sudan University of Science and Technology, P. O. Box 204, Khartoum, SUDAN 
test groups. Shear force in groups D $(3.009 \pm 0.1)$ and $E(3.57 \pm 0.32)$ were not significantly $(\mathrm{P}>0.05)$ higher than the control and the test groups. There were also non-significant $(\mathrm{P}>0.05)$ differences in the sensory evaluation among the control and test groups.

Guinea Fowl

(Numida meleagris) as

a Meat Bird

Originality/value: Guinea fowl can be managed for a fair level of meat production under feeding up to energy and protein requirements. Nutritionally, guinea fowl meat is proving to be a potential competitor in the meat industry; it is rich in crude protein and is classified as white meat. The findings of this study indicate that the crude protein values of guinea fowl ranged between $87.42 \pm 3.16-83.04 \pm 1.58$. These findings are in agreement with the results of Ayorinde (2004) and Sharma and Singh (2006), who reported that guinea fowl contain higher protein (80-87 per cent), more essential amino acids, and lower cholesterol contents than broilers. The findings of this study show that the overall acceptability of guinea fowl meat by the panellists was good. This is in agreement with the results of Mareko et al. (2006) who found that most of the parameters evaluating meat rankings were over 60 per cent (fair to good), showing that guinea fowl meat can be marketed successfully as one of the meat alternatives. Guinea fowl meat is served as a delicacy. The relatively low fat, cholesterol and sodium content of guinea fowl meat, as well as the higher contents of some vitamins, will be a promising tool in the marketing strategies of this meat type as a healthy food.

Keywords: Guinea fowl; Meat quality; Meat chemical composition; Sensory evaluation.

\section{INTRODUCTION}

Guinea fowl (Numida meleagris) is a poultry species suitable for use in meat production (Mandal et al., 1999a). During the last 20 years, much of Europe has switched to this bird to produce meat for luxury markets, and there is still a vast, untapped future for its meat. Guinea fowl can be kept for both meat and egg production and the meat is served extensively in hotels and restaurants because of its wild game flavour. Guinea fowl can be raised under both intensive and extensive management systems (Nsoso et al., 2006). The carcasses have less fat than broilers and pullets and their mineral composition 
IJSR

2,1

is higher. Guinea meat might be a more nutritionally desirable alternative to consumers than meat from other livestock (Santiago et al., 2007). Sharma and Singh (2006) suggested that guinea fowl meat is preferred on account of its dark gamey taste and colour. Guineas provide meat with higher protein, more essential amino acids, lower fat and lower cholesterol contents than broilers (Cappa and Casati, 1978; Singh and Raheja, 1990). Guinea fowl meat could be an excellent and healthy alternative for consumers, and little research has been done on its quality.

\section{MATERIALS AND METHODS}

One hundred and fifty day-old guinea fowl (Numida meleagris galeata) keets were used and raised under a typical poultry intensive pen system. The keets were weighed and randomly allotted to five groups: A, B, C, D and E, each with 30 birds. Food and water were provided ad libitum. The feeding period was continued up to seven weeks, allowing for an initial ten days adaptation period. The experimental diets were formulated to meet the nutrient requirement of broiler chicks according to the National Research Council (NRC) (1984). Crumbled five diets A, B, C, D and E were formulated as in Table 1. The levels of protein and energy were set as follows: high protein high energy, high protein low energy, low protein high energy and low protein low energy for diets B, C, $\mathrm{D}$ and $\mathrm{E}$ respectively. Diet A served as the control diet. Five birds from each group were randomly slaughtered and meat quality was determined. Detection of the colour ordinates (L lightness, a, redness and b, yellowness) were recorded using a portable Spectrocolorimeter-Hunter Lab, colour Flex (model No45/0-USA). Water holding of total lean was determined according to Grau and Hamm (1953). Cooking loss was carried out on the right side breast muscle. Shear force value of cooked breast muscle was prepared according to Babiker 
(1981) for shearing using a QTS Texture analyser (CNS farnell, Essex CM19STG- England). Shear force value (kg/ $\mathrm{cm} 2$ ) was calculated as the mean from five successive cuts. Ultimate $\mathrm{pH}$ was read via a combined electrometer $\mathrm{pH}$ meter (a Thermo Orion, model 900A -USA). The chemical analysis for proximate determination of moisture, crude protein, fat content and ash was carried out according to A.O.A.C. (1980). Results were expressed as per cent composition. Meat samples for sensory evaluation were taken from the drumstick cut. The sample was kept in the deep freezer for test panel

\begin{tabular}{|c|c|c|c|c|c|c|}
\hline Item & Diets & & & & & \\
\hline Ingredient & A & B & $\mathrm{C}$ & $\mathrm{D}$ & E & \\
\hline Yellow corn & 59.80 & 39.70 & 33.46 & 61.35 & 58.70 & \\
\hline Soybean meal & 32.00 & 46.20 & 50.34 & 24.63 & 21.24 & \\
\hline Fishmeal & 03.0 & 03.20 & - & - & - & \\
\hline Wheat (grains) & - & - & 07.0 & 05.0 & 5.00 & \\
\hline Wheat bran & - & - & - & - & 11.20 & \\
\hline Vegetable oil & 01.50 & 06.90 & 05.1 & 04.42 & - & \\
\hline Mineral & 03.60 & 03.90 & 04.0 & 04.50 & 03.76 & \\
\hline Vitamins & 0.10 & 0.10 & 0.10 & 0.10 & 0.10 & \\
\hline Total & 100 & 100 & 100 & 100 & 100 & \\
\hline \multicolumn{7}{|l|}{$\underline{\text { Components }}$} \\
\hline Dry matter & 88.0 & 89.0 & 89.0 & 88.0 & 88.0 & \multirow{6}{*}{$\begin{array}{l}\text { Table I: } \\
\text { Per cent inclusion rate } \\
\text { (by weight) of ingredi- } \\
\text { ents and chemical com- } \\
\text { position (on dry matter } \\
\text { bases) of experimental } \\
\text { diets }\end{array}$} \\
\hline Crude protein & 20.50 & 26.0 & 26.0 & 16.0 & 15.0 & \\
\hline Crude fat & 04.20 & 09.00 & 05.80 & 07.0 & 02.70 & \\
\hline Crude fibre & 02.70 & 02.00 & 02.90 & 02.60 & 03.60 & \\
\hline Ash & 06.50 & 07.00 & 10.50 & 06.20 & 05.80 & \\
\hline $\begin{array}{l}\text { Energy ME } \\
(\mathrm{Kcal} / \mathrm{kg})\end{array}$ & 2990 & 3150 & 2800 & 3150 & 2750 & \\
\hline
\end{tabular}

Guinea Fowl (Numida meleagris) as a Meat Bird 100 
IJSR

2,1

evaluation of colour, tenderness, flavour and juiciness. Ten semi-trained panellists were selected (Cross et al., 1978). The meat samples were cut into small pieces and randomly served warm on coded plates to the panellists. The panellists were asked to score colour, tenderness, flavour and juiciness from an eight-unit scale.

Statistical analysis: The results were statistically subjected to one-way analysis of variance ANOVA (Snedecor and Cochran, 1967).

\section{RESULTS}

The helmeted guinea fowl objective meat quality attributes are presented in Table 2. Treatment groups were not significant $(\mathrm{P}<0.05)$ except for the cooking loss percentage $(22.85 \pm 3.28)$ of group D. The percentage of cooking loss for group D $(22.85 \pm 3.28)$ was higher and significantly $(\mathrm{P}<0.05)$ different when compared with the control group A (15.52 \pm 1.16). Group $B$ had $(P<0.05)$ lighter value than the control. Lightness values in two experimental groups $(\mathrm{C}$ and $\mathrm{E})$ were not significantly $(\mathrm{P}<0.05)$ similar. The water holding capacity value $(2.22 \pm 0.10)$ in the test group $E$ was not significantly higher than the control value $(1.31 \pm 0.78)$, while cooking loss values in the test group D $(22.85 \pm 3.28)$ were significantly higher than the control (15.52 \pm 1.16$)$. Higher non-significant values were recorded for groups $\mathrm{B}, \mathrm{D}$ and $\mathrm{E}$. 


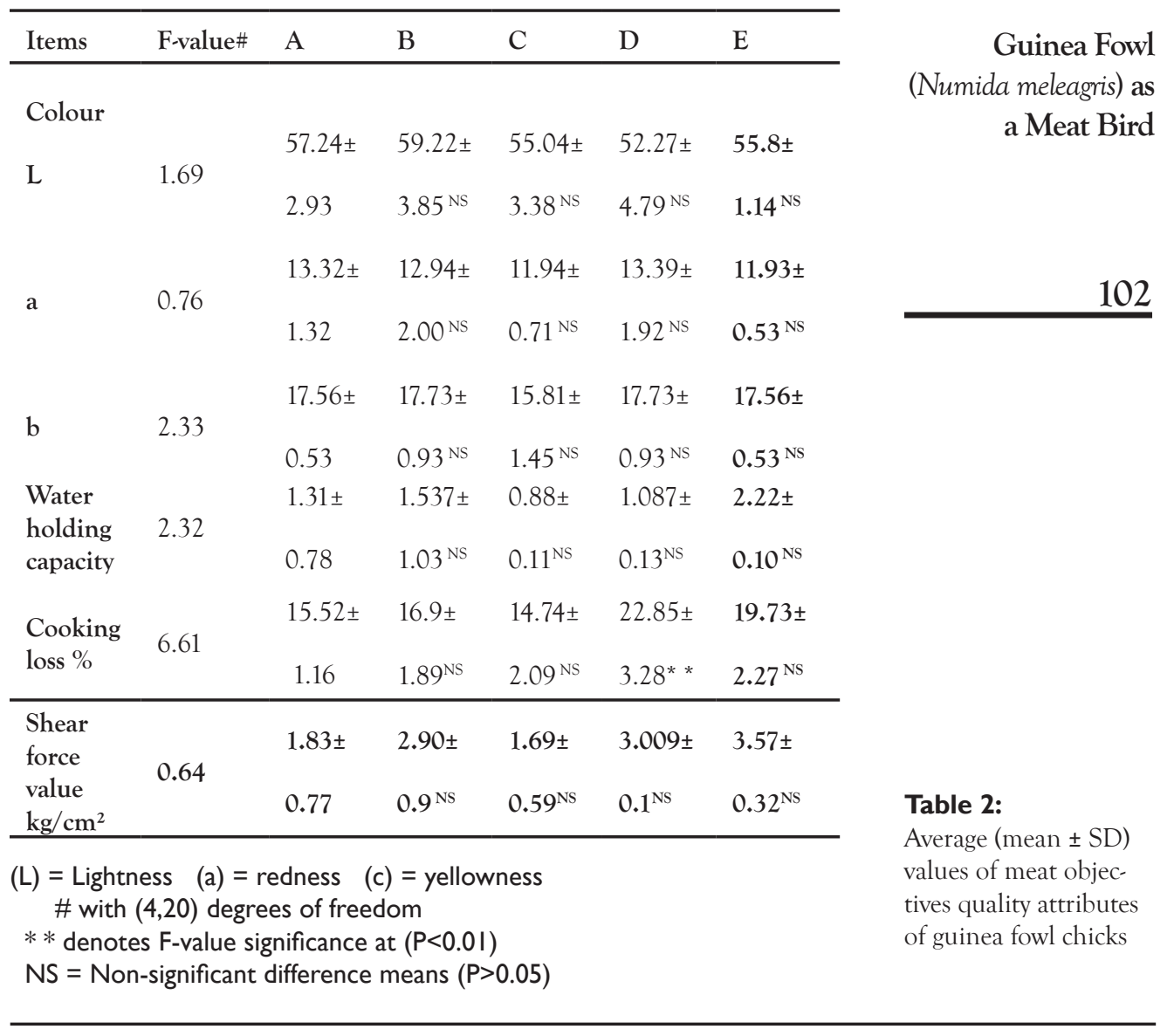

The proximate analysis of helmeted guinea fowl meat is presented in Table 3. Dry matter of group C $(24.19 \pm 0.76)$ was non-significantly $(\mathrm{P}>0.05)$ higher than the control. The crude protein values of groups C $(87.42 \pm 3.16)$ and $E(85.74 \pm 1.36)$ were non-significantly higher than the control $(83.04 \pm 1.58)$. The ether extract value of group C $(5.55 \pm 3.05)$ was non-significantly $(\mathrm{P}>0.05)$ the lowest. The ultimate $\mathrm{pH}$ of all groups were non-significantly $(\mathrm{P}>0.05)$ similar, except group $\mathrm{B}$ $(6.12 \pm 0.026)$ which was significantly different $(\mathrm{P}<0.0)$. 


\begin{tabular}{|c|c|c|c|c|c|c|c|}
\hline \multirow[b]{2}{*}{$\begin{array}{l}\text { IJSR } \\
2,1\end{array}$} & \multirow[b]{2}{*}{ Ingredient } & \\
\hline & & $\begin{array}{l}\text { F- } \\
\text { value\# }\end{array}$ & A & $\mathrm{B}$ & $\mathrm{C}$ & $\mathrm{D}$ & $\mathrm{E}$ \\
\hline \multirow{4}{*}{103} & Dry matter & 6.382 & $\begin{array}{l}23.53 \pm \\
0.4\end{array}$ & $\begin{array}{l}22.32 \pm \\
0.3^{\mathrm{NS}}\end{array}$ & $\begin{array}{l}24.19 \pm \\
0.76^{\mathrm{NS}}\end{array}$ & $\begin{array}{l}21.95 \pm \\
0.98^{N S}\end{array}$ & $\begin{array}{l}21.66 \pm \\
0.98^{*}\end{array}$ \\
\hline & $\begin{array}{l}\text { Crude } \\
\text { protein }\end{array}$ & 1.081 & $\begin{array}{l}83.04 \pm \\
1.5\end{array}$ & $\begin{array}{l}84.31 \pm \\
3.55^{\mathrm{NS}}\end{array}$ & $\begin{array}{l}87.42 \pm \\
3.16^{\mathrm{NS}}\end{array}$ & $\begin{array}{l}84.28 \pm \\
3.48^{\mathrm{NS}}\end{array}$ & $\begin{array}{l}85.74 \pm \\
1.36^{\mathrm{NS}}\end{array}$ \\
\hline & $\begin{array}{l}\text { Ether } \\
\text { extract }\end{array}$ & 1.079 & $\begin{array}{l}8.75 \pm \\
1.64\end{array}$ & $\begin{array}{l}8.16 \pm \\
2.38^{\mathrm{NS}}\end{array}$ & $\begin{array}{l}5.55 \pm \\
3.05^{\mathrm{NS}}\end{array}$ & $\begin{array}{l}9.33 \pm \\
3.23^{\mathrm{NS}}\end{array}$ & $\begin{array}{l}7.96 \pm \\
0.98^{\mathrm{NS}}\end{array}$ \\
\hline & Ash & 5.664 & $\begin{array}{l}4.09 \pm \\
0.22 \\
\end{array}$ & $\begin{array}{l}3.27 \pm \\
0.12^{*} \\
\end{array}$ & $\begin{array}{l}3.81 \pm \\
0.08^{\mathrm{NS}} \\
\end{array}$ & $\begin{array}{l}3.36 \pm \\
0.19^{*}\end{array}$ & $\begin{array}{l}3.45 \pm \\
0.46^{*} \\
\end{array}$ \\
\hline $\begin{array}{l}\text { Table 3: } \\
\text { Guinea fowl meat }\end{array}$ & $\begin{array}{l}\text { Ultimate } \\
\mathrm{pH}\end{array}$ & 3.493 & $\begin{array}{l}5.94 \pm \\
0.05\end{array}$ & $\begin{array}{l}6.12 \pm \\
0.026^{*}\end{array}$ & $\begin{array}{l}6.02 \pm \\
0.09^{\mathrm{NS}}\end{array}$ & $\begin{array}{l}6.06 \pm \\
0.08^{\mathrm{NS}}\end{array}$ & $\begin{array}{l}6.08 \pm \\
0.05^{\mathrm{NS}}\end{array}$ \\
\hline
\end{tabular}

NS $=$ Non-significant difference means $(P>0.05)$

* denotes means values significant $(\mathrm{P}<0.0 \mathrm{I})$

The subjective assessment of meat quality of guinea fowl is shown in Table 4. All parameters were not significantly ( $\mathrm{P}>0.05)$ different. Values for D $(6.7 \pm 1.16)$ and $E(6.8 \pm 0.92)$ tenderness were not significantly $(\mathrm{P}>0.05)$ higher than the control group $(6.2 \pm 1.03)$, while the group B tenderness value $(5.5 \pm 1.58)$ and colour $(5.8 \pm 1.48)$ were not significantly the lowest. Juiciness for all the test groups were non-significantly $(\mathrm{P}>0.05)$ similar to the control value.

\section{DISCUSSION}

In general, meat colour is perceived by consumers as an indicator of freshness. Colour variation in poultry meat depends on primary production factors (breed, age and nutritional status), pre-slaughtering and slaughtering conditions, and subsequent storage (Berri, 2000). The colour results in the present study are supported by the findings of Jaturasitha et al. (2008), who reported that breast and thigh meat colour in 


\begin{tabular}{lllllll}
\hline Items & $\begin{array}{l}\text { F- } \\
\text { value \# }\end{array}$ & $\mathrm{A}$ & $\mathrm{B}$ & $\mathrm{C}$ & $\mathrm{D}$ & $\mathrm{E}$ \\
\hline \multirow{2}{*}{ Tenderness } & \multirow{2}{*}{1.357} & $06.2 \pm$ & $05.5 \pm$ & $06.3 \pm$ & $06.7 \pm$ & $06.8 \pm$ \\
& & 1.03 & $1.58^{\mathrm{NS}}$ & $2.00^{\mathrm{NS}}$ & $1.16^{\mathrm{NS}}$ & $0.92^{\mathrm{NS}}$ \\
\multirow{2}{*}{ Flavour } & \multirow{2}{*}{2.344} & $06.0 \pm$ & $5.3 \pm$ & $06.0 \pm$ & $07.0 \pm$ & $06.4 \pm$ \\
& & 1.41 & $1.64^{\mathrm{NS}}$ & $1.5^{\mathrm{NS}}$ & $0.94^{\mathrm{NS}}$ & $0.7^{\mathrm{NS}}$ \\
\multirow{2}{*}{ Colour } & \multirow{2}{*}{1.318} & $6.6 \pm$ & $5.8 \pm$ & $6.1 \pm$ & $6.5 \pm$ & $07.0 \pm$ \\
& & 0.97 & $1.48^{\mathrm{NS}}$ & $1.79^{\mathrm{NS}}$ & $0.97^{\mathrm{NS}}$ & $0.94^{\mathrm{NS}}$ \\
\hline \multirow{2}{*}{ Juiciness } & \multirow{2}{*}{0.2913} & $5.8 \pm$ & $5.6 \pm$ & $5.5 \pm$ & $6.2 \pm$ & $5.6 \pm$ \\
& & 1.03 & $1.84^{\mathrm{NS}}$ & $2.07^{\mathrm{NS}}$ & $1.75^{\mathrm{NS}}$ & $1.27^{\mathrm{NS}}$ \\
\hline
\end{tabular}

\# with $(4,20)$ degrees of freedom

Ns $=$ Non-significant difference means $(P>0.05)$
Guinea Fowl

(Numida meleagris) as

a Meat Bird

104

\section{Table 4:}

Average (mean $\pm \mathrm{SD})$ values of meat subjective quality attributes of guinea fowl chicks

terms of $\mathrm{L}^{*}, \mathrm{a}^{*}$ and $\mathrm{b}^{*}$ values displayed significant differences among genotypes $(\mathrm{P}<0.001)$. The rate of discolouration in fresh meat is related to the rate of pigment oxidation, oxygen consumption and the effectiveness of the metmyoglobin reducing system (O'Keefe and Hood, 1982; Ledward, 1991; Greene et al., 1971). Water-holding capacity of meat is affected by species, age and muscular function. The present study shows high WHC $(1.537 \pm 1.03,0.8867 \pm 0.11,1.087 \pm 0.13$, $2.22 \pm 0.10)$ compared with poultry $(0.33 \pm 0.01,0.32 \pm 0.01)$ (Musa et al., 2006). Water-holding and shear force capacity are affected by the processing conditions used and period of cold storage. Usually, muscles with a high content of intramuscular fat tend to have a high water-holding capacity (Saffle and Bratzler, 1959). The enhanced loss of water-holding capacity is partly due to increased denaturation of the muscle proteins and partly to enhanced movement of water into the extracellular space (Penny, 1977). Shear force values were linearly related to tenderness scores with high regression coefficients. Shear force values can be used to determine whether meat products vary in texture by measuring the variability in total cutting force. These were highly correlated with overall 
IJSR

2,1

tenderness of muscle. The present study shows similar values of shear force to those obtained by Costa et al. (2007). This value is a highly variable characteristic, depending on many intrinsic and extrinsic factors of the meat and on their interactions (Miller, 1994; Destefanis et al., 2008). Low shear force indicates muscle tenderness. Cooking loss increases by increasing temperature (Sanderson and Vial, 1963). In the present study, cooking loss was higher than that reported by Costa et al. (2007). This may be due to the high muscle moisture content. A quick $\mathrm{pH}$ fall will increase moisture loss during cooking (Sayre et al., 1964).

Guineas are characterized by high meat protein, more essential amino acids, lower fat, and lower cholesterol contents than broilers (Ayorinde et al., 1988; Singh and Raheja, 1990). The present study showed a high meat protein range between $(83.04 \pm 1.5,84.31 \pm 3.5,87.42 \pm 3.16,84.28 \pm 3.48,85.74 \pm 1.36)$. These values are higher than those reported by the Titi Tudorancea Bulletin (2008, [20.6 per cent]).This may be due to physiochemical properties of meat that are affected by intrinsic factors (Carragher and Mathews,1996; Pearson and Gillet, 1999) and may also be due to sample preparation and analytical methods (Holland et al., 1997). Ultimate $\mathrm{pH}$ in the present study ranged between $(5.94 \pm 0.05,6.12 \pm 0.026,6.02 \pm 0.09$, $6.06 \pm 0.08$ and $6.08 \pm 0.05)$ and concords with the results reported by Jaturasitha et al. (2008). These results are lower $(5.72 \pm 0.01$, $5.68 \pm 0.01$ ) than those reported by Musa et al. (2006). The lower $\mathrm{pH}$ of chicken could be due to better welfare conditions that reduce pre-slaughter stress and the consumption of glycogen (Castellini et al., 2002). It could be proposed that genetic strain has a role in the improvement of customer appraisal of poultry meat (Abeni and Bergoglio, 2001). 
Intramuscular fat plays a major role in broiler meat quality, flavour and juiciness (Chizzolini et al., 1999). In the present study, similar results for tenderness, flavour and juiciness were reported by Jaturasitha et al. (2008). High ratings of tenderness, juiciness and acceptability were associated with samples processed using low a smokehouse temperature $\left(80^{\circ} \mathrm{C}\right)$ or high relative humidity ( 85 per cent).

Guinea Fowl

(Numida meleagris) as a Meat Bird

\section{BIOGRAPHY}

D. Aisha Elfaki Mohamed received her Bacalore from Zagazig University, Egypt (1984) in veterinary surgery. She worked as a Veterinary Officer until 1988, when she joined Wad Elmagboul Poultry Project, Ministry of Agriculture and Animal Resources, Khartoum, as Production Manager. Meanwhile she attained her MSc in Animal Production at the Faculty of Animal Production, Khartoum University, Sudan, and her PhD in Ratite Medicine at the Faculty of Veterinary Science, University of Khartoum, Sudan. She joined the Wildlife Research Center as assistant researcher in 1998, became a researcher in 1999, assistant professor from 2001-2006 and has been an associate professor since 2006. She was appointed Head of the Department of Wildlife Diseases, Breeding and Production at the Wildlife Research Center, Sudan 2003-2009. Her current position is Associate Professor, Director of Wildlife Research Centre, Animal Resources Research Corporation, Federal Ministry of Animal Resources, Fisheries and Range. Her research has covered wild animal health and production, wild bird diversity and red-necked ostrich Struthio camelus camelus nutrition, diseases, behaviour, meat yield and quality, captive ostrich diseases and affection, and genetic diversity in the Sudanese ostrich. She has authored numerous publications including work on promoting poultry nutrition, wildlife diseases, and ostrich breeding and management. She is a member of the Sudan 
IJSR

2,1

Veterinary Union, 1987, Sudan Veterinary Council, 2000, Sudan Wildlife Society, 2001, Third World Organization for Women of Science (TWOWS), 2003, World Poultry Science Association (WPSA), 2005, Ratite Working Group, 2005, Secretariat General of Consultancy Board, Ministry of the Cabinet, Sudan, 2008, and the Research Coordination Council Livestock Research, Sudan Academy of Science.

Zohair Magzoub Mohamed Elhag received his Bacalore from the Faculty of Veterinary Science, Khartoum University, Sudan (1989). He worked as a Veterinary Officer in Butana Dairy Farm, Khartoum Dairy Production CO. LMD (19901993), then joined Gabis Veterinary Services (1993-1997). He joined the Agricultural Department, Veterinary Section, Al Ain-United Arab Emirates in 1999 and was assigned to H. H. SH. Sultan bin Zayed Private Department as wildlife supervisor until 2007. He has held his current position in Abu Dhabi, United Arab Emirates, as a wildlife consultant on Dorsch Gruppe since 2007. He attained his MSc (Wildlife Science) from the Department of Fisheries and Wildlife Biology, College of Animal Production Science and Technology, Sudan University of Science and Technology. He is a member of Sudan Veterinary Council and the Wildlife Disease Association (WDA).

Prof. Ali Saad Mohamed graduated from the University of Khartoum in 1971 as a veterinary surgeon. He was promoted to District Veterinary Officer in 1973 and worked as a Zoo Veterinary Officer from 1973-1975. In 1975 he was admitted to the college of Forestry and Natural Resources, Colorado State, USA, where he was awarded his MSc in 1977. He joined Sudan Agricultural Corporation and was promoted to associate research scientist in 1991 . He attained his $\mathrm{PhD}$ (1994) from the Gezira University, Sudan. In 1997 he joined Sudan University of Science and Technology, where he was 
promoted to professor status in 2000 . He has published about twenty-five papers in the field of wildlife and supervised four $\mathrm{PhD}$ candidates and ten MSc candidates. He is a member of the Sudan Veterinary Association, Sudan Environmental Society and Sudanese Wildlife Society.

\section{REFERENCES}

Abeni,F. and Bergogoglio, G. ( 2001), "Characterization of different strains of broiler chicken by carcass measurements, chemical and physical parameters and NIRS on breast muscle", Meat Science, Vol. 57, pp. 133-137.

A.O.A.C. (1980), Official Method of Analysis, $12^{\text {th }} \mathrm{ed}$. Association of Official Analytical Chemists, Washington, D.C., USA.

Ayorinde, K.L. (2004), The spice of life (the seventy first inaugural lecture), Library and Publications Committee. University of Ilorin, Nigeria.

Ayorinde, K.L., Toye, A. A. and Aruleba, O.A. (1988), "Association between body weight and some egg production traits in a strain of commercial layer", Nigeria Journal of Animal Production, Vol. 15, pp. 119-121.

Babiker, S.A. (1981). Accelerated Processing of Beef in Relation to Ambient Temperature. Ph.D. Thesis, University of Nottingham, England.

Berri, C. (2000), "Variability of sensory and processing qualities of poultry meat", World's Poultry Science Journal, Vol. 56, pp. 209-224.

\section{(Numida meleagris) as} a Meat Bird 
IJSR

2,1

Cappa, V. and Casati, M. (1978), "Experiments of growing guinea fowl, amino acid composition of the carcass", Avicoultura, Vol. 47 No. 3. pp. 21-29.

Carragher, J.F. and Mathews L.R. (1996), "Animal behavior and stress. Impacts on meat Quality", Proceedings New Zealand Society of Animal Production, Vol. 56, pp. 162-166.

Castellini, C., Mugnai, C. and DalBosco, A. (2002), "Effect of organic production system on broiler carcass and meat quality", Meat Science, Vol. 60, pp. 219-225.

Chizzolini, R., Zanardi, E., Dorigoni, V. and Ghidini, S. (1999), "Calorific value and cholesterol content of normal and low fat meat and meat products", Trends in Food Science Technology, Vol. 10, pp. 119-128.

Costa, A.I.A., Teldeschi, E. Gerritzen, M.A., Reimert, H.G.M., Linssen, J.P.H. and Cone, J.W. (2007), "Influence of flock treatment with the antibiotic tylosin on poultry meat quality: results of a preliminary experiment", NJAS, Vol. 54 Issue 3, pp. 269 -278.

Cross, H.R. Moen, R. and Stanfield, M.S. (1978), "Training and testing of judges for sensory analysis of meat quality", Food Technology, Vol. 37, p.48.

Destefanis, G. Brugiapaglia, A. Barge, M.T. and Dal Molin, E. (2008), "Relationship between beef consumer tenderness perception and Warner-Bratzler shear force", Meat Science, Vol. 78, pp. 153-156.

Grau, R. and Hamm, R. (1953), Eime eintache methods, Zur bestimmung der Wasserbindung in musked. Die Naturwissenscheften, Vol. 40, 29-30. 
Greene, B.E. Hsin, I.M. and Zipser, M.W. (1971),

"Retardation of oxidative colour changes in raw ground beef”, Journal of Food Science, Vol. 36, pp. 940-942.

Holland, B. Welch, A.A. Unwin, I.D. Buss, D.H. Paul, A.A. and Southgate, D.A.T. (1997), McCance and Widdowson's The Composition of Foods, $5^{\text {th }}$ edn. The Royal Society of Chemistry, Redwood Books, Ltd., Trowbridge, Wiltshire, UK.

Jaturasitha, S. Srikanchai ,T. Kreuzer, M. and Wicke, M (2008), "Differences in carcass and meat characteristics between chicken indigenous to Northern Thailand (Black-boned and Thai Native) and imported extensive breeds (Bresse and Rhode Island Red)", Poultry Science, Vol. 87, pp.160-169.

Ledward, D. A. (1991), "Colour of Raw and Cooked Meat”, in Johnsten, D.E., M.K. Knoght and D.E. Ledward, (Eds.), The Chemistry of Muscle-Based Foods, The Royal Society of Chemistry, Cambridge, UK, pp. 128-144.

Mandal, A. B., Pathak, N. N. and Singh, H. (1999a), "Energy and protein requirements of guinea keets (Numida meleagris) as meat bird in a hot humid climate”, Journal of the Science of Food and Agriculture, Vol. 79 No. 4, pp. 523-531.

Mareko, M.H.D., Nsoso, S.J. and Thibelang, K.(2006), "Preliminary carcass and meat characteristics of Guinea fowl (Numidia meleagris) raised on concrete and earth floors in Botswana”, Journal of Food Technology, Vol. 4 No. 4, pp. 313-317.
Guinea Fowl (Numida meleagris) as a Meat Bird 
IJSR

2,1
Miller, M.S. (1994), "Proteins as fat substitutes", in Hettiarachchy, N.S.and G. R. Ziegler (Eds.), Protein Functionality in Food Systems, Marcel Dekker Inc., New York, NY.

Musa, H.H. Chen, G.H. Cheng, J.H. Shuiep, E.S. and Bao, W.B. (2006), "Breed and Sex Effect on Meat Quality of Chicken”, International Journal of Poultry Science, Vol. 5 No. 6, pp. 566-568.

National Research Council (1991), Micro-livestock: Little known (grasscutter) animals with promising economic future, Xvii x 449 (Viet Meyer Noel Ed.). National Academy Press, Washington, D.C.

Nsoso, S.J., Mareko, M .H.D. and Molelekwa, C. (2006), "Comparison of growth and morphological parameters of guinea fowl (Numida meleagris) raised on concrete and earth floor finishes in Botswana”. Livestock Research for Rural Development, Vol. 18 No. 12. http://www.cipav. org.co/lrrd/lrrdl 8/12/nosl 8178.htm

O'keefe, S.F. and Hood, D.E. (1982), "Biochemical factors influencing metmyoglobin formation on beef from muscles of differing color stability", Meat Science, Vol. 7, pp. 209-228.

Pearson, A. M. and Gillet, T.A. (1999), Processed Meats $3^{\text {rd }}$ edn. An Aspen Publishers Inc. Maryland, USA.

Penny, I.F. (1977), "The effect of temperature on the drip, denaturation of extracellular space of pork longissimus dorsi muscle", Journal of the Science of Food and Agriculture, Vol. 28, pp. 329-338. 
Saffle, R.L. and Bratzler, L.J. (1959), "The effect of fatness on some processing and palatability characteristics of pork carcasses", Journal of Food Technology, Vol. 13, pp. 236-238.

Sanderson, M. and Vial, G. E. (1963), in Meat Science, Ed. R.A. Lawrie, $3^{\text {rd }}$ edn., Pergamon Press, Oxford.

Santiago, H.L., Díaz,V. and Rodríguez, A.A. (2007), "Processing yields, meat quality attributes and nutrient composition of diverging genotypes of guinea fowl (Numida meleagris) broilers reared on various planes of nutrition in a tropical environment", Animal Science, Vol. 13, pp.236-238.

Sayre, R.N. Nievant, B.and Briskey, E.J. (1964), "Processing characteristics of porcine muscle related to $\mathrm{pH}$ and temperature during rigor mortis development and to gross morphology 24 hr post-mortem”, Journal of Food Science, Vol. 29, pp.175-181.

Sharma, D. and Singh, H. (2006), "Future research priorities in guinea fowl breeding and Genetics", Poultry Research Priorities to 2020. pp. 22-30.

Singh, H. and Raheja, K. L. (1990), "Genetic estimates of cholesterol and high density lipid components in indigenous guinea fowl serum", in Proceedings of XI I Annual Conference and Symposium of Indian Poultry Science Association. Bombay Veterinary College, Bombay, India.

Snedecor, G.W. and Cochran, W.G. (1967), Statistical Methods. Iowa State University Press. Ames, Iowa, USA. Titi Tudorancea Bulletin, (2008), Nutrition, Guinea hen, meat only, Raw Nutrition Facts.
Guinea Fowl (Numida meleagris) as a Meat Bird 